UDC $81-139$

DOI https://doi.org/10.32838/2710-4656/2021.4-1/34

Motrynets $\boldsymbol{E} . \boldsymbol{O}$.

Ferenc Rakoczi II Transcarpathian Hungarian College of Higher Education

Nagy-Kolozsvari E. A.

Ferenc Rakoczi II Transcarpathian Hungarian College of Higher Education

\title{
EXPLOITING LITERATURE IN THE EFL CLASSROOM: GRADED READERS AS A MEDIUM FOR PROMOTING ENGLISH LANGUAGE LEARNING TO EFL LEARNERS
}

English, being an international language, is taught in the majority, if not all of the schools/ educational institutions in our country. In the classroom teachers usually use a number of techniques and teaching methods in order to help students to learn the language. In recent years, however, many teachers have realised that the methods and techniques used in EFL classrooms are not always as effective as they would hope. According to a number of scholars a possible solution to this problem would be the use of literature in the EFL classroom.

As Kaya [18, p. 41] states, literature allows students to improve their language level, as well as work on their language skills and vocabulary. Moreover, it can be stated, that graded readers are considered to be great sources of reading materials, as their vocabulary and grammar are simplified, which allows learners to practice the grammar and vocabulary that they already know [28].

Therefore, in our study we have tried to tackle the issue of introducing literature and graded readers into the foreign language classroom in Transcarpathia from three perspectives, thus gaining an insight into teachers' and learners' attitudes concerning this topic, as well as providing a detailed description of the activities and approaches that can help teachers to incorporate literary works into their language classrooms. The triangulation method was applied, which means that multiple qualitative research methods were involved in developing a comprehensive understanding of the phenomena. The research part of this study addresses a number of important questions and provides an example of how literature and a graded reader can be used in an actual EFL classroom, as previous studies dealing with this topic were mainly conducted abroad. The object of our study was the concept of using literature in foreign language teaching, while the subject of the study was the introduction of grade readers in the EFL classroom.

Key words: foreign language teaching, literature, reading in a foreign language, graded readers, Transcarpathia.

Problem statement. It is generally known that teaching a foreign language is not an easy task. Numerous teaching methods and approaches have been developed throughout the years, yet none can be considered perfect as their effectiveness depends on internal and external factors.

Like many other languages, English has been taught as a foreign language (FL) for decades worldwide. Some teaching methods incorporated literature in their curriculum as literature and literary texts were considered very useful when teaching a foreign language.

However, there is little evidence to prove that (1) literature and graded readers are frequently used in foreign language teaching in Transcarpathia, or (2) that introducing such reading materials is an effective way of teaching English, which determined the focus of our study.
Literature review. Many researchers highlight the relevance of using literature in the foreign language classroom when teaching a foreign language. Armstrong [5, p. 7] and Hall [15, p. 48] agree that using literature in the language classroom gained popularity with the appearance of the communicative language teaching approaches. Moreover, literary materials are often included in extensive reading (ER) programs designed for foreign language learners. Day and Bamford [11] argue that ER can help students enjoy and love reading in a foreign language.

It can be stated that literature might help learners to achieve better results when learning a foreign language. Using literature is a great way of introducing new vocabulary and, at the same time, an excellent opportunity for the students to get familiar with their target culture. According to Koutsompou [19, p. 74], 
literature is closely related to language. Moreover, as Kaya [18, p. 41] states, it can help learners enrich their language knowledge and improve their language skills. Other scholars, including Day \& Bamford [11], Lazar [20], Nazara [22], Daskalovska \& Dimova [10], Waring \& Takahashi [31] and others, wrote about the positive impact of including literature and literary works in the foreign language syllabus.

According to Floris [14], although teachers and course books tend to use informative texts to teach foreign languages, literature and literary texts also have numerous distinctive qualities that make them suitable for EFL classrooms. Moreover, Healy [17] believes that literature encourages students to learn a new language and at the same time learn to share their thoughts and feelings in that particular language.

Pardede [23, p. 14] argues that although many teachers believe focusing on linguistic elements in an EFL classroom is enough, teaching trends have changed in recent years. Using literature in EFL has become advisable as it provides examples of authentic language use. Moreover, as Lazar [20] writes, unfortunately, many learners are limited in using spoken English in their countries, which means they get most of their knowledge and information through written English. It is one more reason why literature might become so important in the process of foreign language acquisition "as it provides meaningful and memorable contexts for processing and interpreting new language" [20, p. 17].

Collie and Slater [9, p. 5-7] give several reasons for using literature in the language classroom: (1) Valuable, authentic material. The word 'authentic' refers to the fact that literary works are not explicitly written for language learners. Thus, the language of such reading materials reflects 'real' language use. (2) Cultural enrichment. Unfortunately, most language learners cannot spend an extended period of time in a country where English is the native language; therefore, literature might help them understand the target culture. (3) Language enrichment. Although it can be debated whether an authentic literary work can provide learners with useful language and vocabulary, Collie and Slater believe that the literary text will prove beneficial if the teachers choose wisely. (4) Personal involvement. When learners have to explore a story over a longer time, they can focus on the storyline instead of individual structures and words. Moreover, they might become emotionally attached to certain characters.

It can be said that there are many reasons to include literature in language teaching. However, before deciding whether to use literary texts in the language classroom, teachers should consider the advantages and disadvantages of incorporating literature in the teaching process.

\section{Advantages of Using Literature in EFL}

There are numerous advantages of incorporating literature into the foreign language classroom. Claudia Ferradas [13, p. 27] enumerates several positive effects of using literature in the language classroom. In short, she argues that literature can motivate learners, and it is often very thought-provoking.

Moreover, literature helps learners improve their language skills and expand their vocabulary, not to mention that it is an excellent way of developing the learners' cultural awareness [13]. Rai [25, p. 71] states that apart from developing the learners' four language skills, using literature also helps improve different language areas, such as their vocabulary and grammar and pronunciation.

Koutsompou [19, p. 74] also writes about the positive effects of using literature in the language classroom, making the class more "lively and motivating".

\section{Disadvantages of Using Literature in EFL}

However, it should be mentioned that although reading in a foreign language might help students learn a new language, many difficulties will most certainly arise.

Some of the difficulties mentioned by Scrivener [27] are (1) lack of vocabulary needed to understand a particular text, (2) which might result in students constantly using a dictionary, (3) and the process of reading itself might be very slow compared to the time we spend on reading the same text in our native language, (4) not to mention that sometimes learners will understand individual words and still not get the whole meaning.

Moreover, Floris [14] states that literary texts and literary language itself might become a 'hindrance' in an EFL classroom as it might seem 'incomprehensible' at times. Furthermore, such texts tend to be quite long, and in this case, the length of the text can also cause difficulties. Lima [21, p. 4] points out that the language of literary works can often be characterized by the "intentional bending and breaking of grammatical rules", especially if the teacher decides to use authentic literature instead of graded or simplified reading materials.

Another aspect that might cause difficulties, as Shella [28] mentioned, is that choosing an appropriate reading material might turn out to be surprisingly challenging. However, even if the reading material is suitable, learners still do not wish to engage in the reading activities or read at all. 


\section{Graded readers}

Another frequently mentioned term closely related to introducing literary works into the EFL classroom is the notion of graded readers. As Albay [4, p. 177] claims, graded readers "are particularly designed to enable learners to practice reading skills and provide an opportunity to reinforce known vocabulary".

Waring \& Takahashi [31, p. 9] also mention that some graded readers include different comprehension questions and a glossary of words that appear throughout that particular story. Moreover, graded readers are usually divided into different levels based on their grammatical structure difficulty and vocabulary number.

According to Shella [28], the effectiveness of graded readers can be explained by the fact that they have severely restricted (or simplified) vocabulary and grammar, thus making it much easier for learners to practice their target language and improve their reading skills. Waring \& Takahashi [31, p. 9] also write about the positive effects of using graded readers. According to them, such reading materials can be used even with beginners, who can start by reading the easiest levels and slowly make their way towards the more complex, more difficult levels of graded reading materials.

The purpose of the research. The issue of using literature in language teaching has been investigated by several scholars, including Armstrong [5], Bloemert, Paran, Jansen, \& van de Grift [6], Bobkina \& Dominguez [7], Erkaya [12], Rai [25], Skog [29], Tevdovska [30], Іщук А. А. [1], Кузнєцова Л.А., \& Лотоцька К.Я. [2] and others. Moreover, many studies show how literature affects the learners' language skills development and their overall language proficiency levels. Some of the previously conducted studies are summarized below.

Akbari \& Razavi [3] conducted a study to assess the attitudes of English language teachers towards the use of authentic (reading) materials. Their research focused on receptive language skills, that is, on listening and reading skills. Raveanová [26] researched the use of graded readers in adult education and focused on teachers' attitudes. Skog's [29] survey centred around novels in EFL classrooms in a few Swedish secondary schools. Haroon, Mohammed, \& Khanday [16] conducted a study amongst English teachers "about the importance of using Graded Readers or Simplified Readers (SRs) in motivating students to read extensively outside the classroom." Yang's [32] study focused specifically on using short stories in language instruction as these are considered good teaching resources. The researcher aimed to investigate whether using short stories in teaching English would increase interest levels among the learners. Tevdovska's [30, p. 165] aim was "to investigate students' attitudes towards the impact of literary texts on language learning and teaching". Nazara [22] conducted her research to find out whether learners enjoyed learning vocabulary through the medium of short stories.

The purpose of this paper is to investigate the relevance and effectiveness of using literature in language teaching. Many studies show how literature affects the learners' language skills development and their overall language proficiency levels. However, based on previous investigations, we have decided to research whether the practice of including literature in the foreign language classroom is familiar to English teachers in Transcarpathia and its efficiency in the classroom.

This study aimed to investigate the use of graded readers in the foreign language classroom from three perspectives. The triangulation method was applied, which means that multiple qualitative research methods were involved in developing a comprehensive understanding of the phenomena. The empirical questionnaire and quasi-experimental research methods were chosen to assess the learners' and teachers' attitudes towards using literature and graded readers in the EFL classroom. On the one hand, the study evaluated the attitudes of English teachers in this region towards using literature in the EFL classroom and their opinions about using graded readers with the help of a questionnaire. On the other hand, this study tested whether using literature and graded readers when teaching a foreign language helps students' language skills. A small scale case study was conducted in a senior secondary school (the case study involved: using a graded reader in the English classroom for six weeks, comparing the results of a pre- and post-test, designing exercises and activities used alongside the graded reader and the activities that are included in the reader). Finally, at the end of the reading programme, learners' attitudes were also assessed with a student questionnaire regarding the use of literature and graded readers in the English classroom.

The hypothesis was that using literature, precisely graded readers (1) helps learners to improve their reading comprehension skills and to build their vocabulary; (2) make the process of language learning more engaging and more effective; (3) motivates the students to read more in their target language. Moreover, (4) English teachers in Transcarpathia are not aware of the benefits of using graded readers; 
therefore, (5) most English teachers in our region do not use graded readers in the EFL classrooms.

In this study, the following questions were answered: (1) Does including literature/graded readers in the foreign language classroom positively affect learners' language skills? (2) Do language learners enjoy reading graded readers? (3) Do English teachers (in this region) use graded reading materials in their English lessons?

Participants. The first group of participants comprises the learners of a Transcarpathian senior secondary school. In this investigation, the ninth and the tenth form students were involved for two reasons. Firstly, according to Erkaya [12] and Nazara [22], although literature and graded reading materials can be introduced into the EFL classroom even at lower levels, as it is a great way of developing the learners' vocabulary, in the case of (pre)intermediate students, literature can prove to be helpful when developing other language skills as well (e.g. the learners' speaking or writing skills). Therefore, considering that two classes used a coursebook at the preintermediate level in our target school, we decided to test the effectiveness of using graded readers in foreign language teaching in these forms.

Secondly, although both forms use a B1-B2 level coursebook, the number of English lessons per week is very different in both cases. While in the case of form nine, there are two English lessons each week, in the case of form ten, the number of English lessons per week is five. Thus, using a graded reader in the EFL classroom in these two forms allowed us to compare the final test results to see if there was a substantial difference between the two cases.

In total 30 learners were involved in the research $(\mathrm{N}=14$ tenth grade; $\mathrm{N}=16$ ninth grade). Because the learners come from different parts of Transcarpathia, their previous learning experiences are entirely different. As a result, their language levels vary between elementary and intermediate (according to the Common European Framework of Reference for Languages).

During the spring semester, the teacher introduced a graded reader into the English language classroom. It was used inside and outside the classroom for six weeks (from 15 February to 26 March 2021). During this time, the learners were required to: (1) read several chapters from the graded reader; (2) do preand post-reading exercises and activities; (3) do a prereading test before the study; (3) do a post-reading test at the end of the study; (4) learn new vocabulary items provided by the graded reader; (5) fill out a post-reading questionnaire.
The second group of participants included Transcarpathian English teachers

working in primary or secondary schools, as well as those working in language schools $(\mathrm{N}=32)$. A survey was used to assess the teachers' attitudes towards using literature and graded readers in the EFL classrooms.

The instruments used in this study were the following:

(1) a questionnaire consisting of multiple-choice questions as well as open-ended and closed-ended questions which aimed at assessing the teachers' attitudes toward using literature in the EFL classroom (based on two previous studies conducted by Skog [29] and Raveanová [26]).

(2) pre- and post tests based on a graded reader (The Sign of Four retold by Anne Collins) and a number of activities and tasks based on that same literary work;

(3) a second questionnaire consisting of thirteen Likert scale statements aimed at assessing the learners' opinions concerning the use of graded readers in the English lessons (based on three previous studies conducted by Pathan [24], Cheetham, Harper, Elliott, \& Ito [8], and Tevdovska [30]).

Thus, it can be stated that the researcher used a mixed-methods approach to collect both qualitative and quantitative data.

Results. Results of the first questionnaire regarding teachers' attitudes. Almost half of the respondents (14) have been teaching English as a foreign language for more than ten years. Moreover, there were 9 teachers with teaching experience between 6-10 years and another 9 teaching for a maximum of five years.

As the results show, the majority of teachers are aware that extensive reading, done in the learners' target language is very beneficial. Moreover, all of the respondents stated that they recommended their learners to read as much as possible in English. Furthermore, most of these respondents use some form of literature in their foreign language classrooms. However, it should also be noted that most teachers resort to using shorter reading materials, such as short stories, articles, poems, etc. This might be explained by the fact, that reading such texts requires little time and can often be done inside the language classroom. Moreover, it can be said that the majority of the respondents prefer choosing the reading materials themselves, or in some cases, they allow their learners to choose from a variety of selected materials, and only a few of the teachers allow the learners to read whatever they want. 
Most of the teachers were familiar with such reading materials when using graded readers, though not all of them use them in language instruction. Though there are many reasons a teacher might choose not to include graded readers in the foreign language classroom, it seems that one of the main reasons for doing so in Transcarpathia is time limitation, which is quite common. These responses were in line with the results of Raveanová's [26] research and the findings of Haroon, Mohammed, \& Khanday [16]. However, those teachers who use graded readers are well aware of the benefits of reading materials on the learners' language skills and overall language proficiency.

It can also be stated that the majority of teachers agreed with the common statements concerning the use of literature and graded readers in the EFL classroom. Most of them were aware of the fact that while reading such books, learners tend to learn a lot and that the content of these books is also a major contributing factor to the success of such reading activities. The majority of the teachers also agreed that graded readers could help their learners to develop reading confidence. However, it is important to choose the most appropriate level of graded readers for the learners, while an overly complicated text with lots of unknown words might simply discourage learners. Finally, almost all respondents agreed that using literature is an excellent way of teaching our learners culture and cultural values.

Results of the pre- and post tests based on the graded reader. To analyze the scores of the preand the post-tests paired sample t-test and descriptive statistics were used with the help of SPSS data analysis statistical software. The t-test is used to compare two sets of scores in order to determine whether the average score (called the mean score) of the first set is significantly higher/lower than the second set.

Results for a paired t-test in form 9

\begin{tabular}{|l|c|c|c|c|c|c|}
\hline & $\begin{array}{c}\text { Mean } \\
\text { (out } \\
\text { of 16) }\end{array}$ & SD & N & p-value & t-statistic & df \\
\hline $\begin{array}{l}\text { Pre- } \\
\text { test }\end{array}$ & 8.88 & 1.59 & 16 & 0.2591 & 1.1729 & 15 \\
\hline $\begin{array}{l}\text { Post- } \\
\text { test }\end{array}$ & 9.94 & 2.84 & 16 & & & \\
\hline
\end{tabular}

The two-tailed $\mathrm{P}$ value equals 0.2591. By conventional criteria, this difference is considered to be not statistically significant $t(15)=1.1729, p=.25$, but the Cohen's $d$ effect size $(\mathrm{d}=0,461)$ is small. There are therefore, good reasons to think that learners need more time when graded readers are used although this should be tested with a larger sample size to increase the power of the paired t-test.

Table 2

Results for a paired t-test in form 10

\begin{tabular}{|l|c|c|c|c|c|c|}
\hline & $\begin{array}{c}\text { Mean } \\
\left(\begin{array}{c}\text { out of } \\
\text { 14) }\end{array}\right.\end{array}$ & SD & $\mathbf{N}$ & p-value & t-statistic & df \\
\hline $\begin{array}{l}\text { Pre- } \\
\text { test }\end{array}$ & 10.57 & 1.02 & 14 & 0.0130 & 2.8762 & 13 \\
\hline $\begin{array}{l}\text { Post- } \\
\text { test }\end{array}$ & 9.07 & 2.27 & 14 & & & \\
\hline
\end{tabular}

The two-tailed $\mathrm{P}$ value equals 0.0130. By conventional criteria, this difference is considered to be statistically significant. A paired t-test found that there was a statistical difference between test results in form $10, t(13)=2.87, \mathrm{p}=.01$, but the Cohen's $d$ effect size $(d=852)$ was large, which means the use of graded readers can be beneficial in teaching EFL, but it also should be tested with a larger sample size for a longer period of time.

The results were quite different in both forms. While in the case of form 9 there was an improvement when using a graded reader in language instruction, in the second case, these were quite the opposite, as learners in form 10 received better grades for the prereading tests. In both cases, the first pre/post-reading tests were more successful than the ones written three weeks after finishing a certain topic, which proves that learners tend to forget part of the material/vocabulary they have already learnt.

The use of graded readers had different effects on the two forms. Interestingly enough, even though form 9 learners were required to do much more reading outside the classroom on their own, they did achieve better results in the post-reading tests. However, it should also be noted that due to several restrictions brought on by the pandemic, the learners were forced to study online for almost a month, making it more challenging to use the graded reader successfully.

Results of the student questionnaire. The second question in this study was the following: Do language learners enjoy reading graded readers? To answer this question, the researchers designed a questionnaire for learners in which they were asked to rate each statement according to the Likert scale (' 1 ' - strongly disagree, ' 5 ' - strongly agree).

The items of the questionnaire were designed based on the above mentioned previous studies. To check the internal consistency and validity of the multi-item scales, Cronbach's Alpha was calculated with the help of the SPSS software package. 
Cronbach's Alpha can be written as a function of the number of test items and the average intercorrelation among the items. Below, we show the formula for the Cronbach's alpha:

$$
\alpha=\frac{N \bar{c}}{\bar{v}+(N-1) \bar{c}}
$$

Here $N$ is equal to the number of items, $\bar{c}$ is the average inter-item covariance among the items and $\bar{v}$ equals the average variance.

Based on our first calculations, the result of Cronbach's Alpha was .524 (Table 3), which means the results would not prove highly reliable. However, having examined the scale variance if item deleted (Table 4) and Cronbach's Alpha, if item deleted, we decided to exclude Q4 and Q12 from the analysis to increase the result $\alpha=.593$ which is closer to acceptable.

According to the results, the learners responded quite positively to the use of graded readers. Most of them were willing to read the book both inside and outside the classroom. The learners, in general, did not find reading the graded reader too difficult, and the majority of them agreed that even though they had to do much reading, it did not feel like studying to them. Moreover, very few learners had major difficulties in understanding the plot of the story, or the text in general, which might explain why most of them enjoyed reading the graded reader more than the text found in their course books.
Although learners enjoyed reading, not all of them could say that using the graded reader helped them improve their language proficiency level. However, most of them did believe that their reading comprehension skills and reading speed have improved. Moreover, some of them stated that their vocabulary has also improved. Another important finding was that even though the learners had to do a number of exercises and activities before, while, and after reading each chapter, they enjoyed them. This might be because some of these activities helped them better understand the story itself and allowed them to express their own ideas and thoughts regarding the plot and the characters. These results are similar to Nazara's [22] findings, as she also stated that her participants enjoyed reading in their target language, and their motivation and activity levels also improved. Moreover, the fact that some learners were already familiar with Sherlock Holmes's character and some of the Sherlock stories made it easier for them to fully understand the plot.

Conclusions. The theoretical value of this study was that it presented a detailed overview of the main aspects of using literature and graded readers in the foreign language classroom, while the practical value of this study was that it contributed to the field of language teaching with presenting the results of a research that provided some insight into the importance of literature in foreign language teaching.

This study focused on exploiting literary works, and more importantly, graded readers in

Table 3

Reliability Statistics

\begin{tabular}{|c|c|c|}
\hline Cronbach's Alpha & Cronbach's Alpha Based on Standardized Items & N of Items \\
\hline, 491 &, 524 & 13 \\
\hline
\end{tabular}

Table 4

Item-Total Statistics

\begin{tabular}{|c|c|c|c|c|c|}
\hline & $\begin{array}{c}\text { Scale Mean if Item } \\
\text { Deleted }\end{array}$ & $\begin{array}{c}\text { Scale Variance if } \\
\text { Item Deleted }\end{array}$ & $\begin{array}{c}\text { Corrected Item- } \\
\text { Total Correlation }\end{array}$ & $\begin{array}{c}\text { Squared Multiple } \\
\text { Correlation }\end{array}$ & $\begin{array}{c}\text { Cronbach's Alpha } \\
\text { if Item Deleted }\end{array}$ \\
\hline Q1 & 40,467 & 24,257 &, 458 &, 553 &, 406 \\
Q2 & 40,133 & 27,154 &, 079 &, 649 &, 499 \\
Q3 & 40,233 & 24,944 &, 338 &, 620 &, 432 \\
Q4 & 41,833 & 29,109 &,- 081 &, 615 &, 542 \\
Q5 & 41,100 & 25,610 &, 252 &, 817 &, 453 \\
Q6 & 40,733 & 25,237 &, 312 &, 831 &, 439 \\
Q7 & 41,867 & 25,223 &, 219 &, 573 &, 460 \\
Q8 & 40,467 & 26,602 &, 125 &, 425 &, 487 \\
Q9 & 40,000 & 25,448 &, 309 &, 525 &, 441 \\
Q10 & 40,367 & 26,447 &, 262 &, 614 &, 456 \\
Q11 & 41,200 & 25,476 &, 165 &, 434 &, 477 \\
Q12 & 40,767 & 28,116 &,- 004 &, 548 &, 521 \\
Q13 & 40,033 & 27,482 &, 107 &, 473 &, 488 \\
\hline
\end{tabular}


the FL classroom. After analyzing the (learner/teacher) questionnaires we concluded, that including literature in the foreign language classroom can potentially have a positive effect on the learners' language skills; however, the results might be completely different in each case.

On the one hand, literature does help learners to enrich their vocabulary, as well as allows them to learn more about their target culture. Moreover, the process of language teaching/learning becomes more exciting and enjoyable as the learners' responses reflect.

On the other hand, this type of teaching approach will not be equally effective in every classroom, as its success rate depends on some factors, including the learners' interest and willingness to read large amounts of texts, as well as the type of materials selected by the teacher/learners, etc. Although using graded readers in the EFL classroom might not prove to be effective in a short period of time, the learners' responses prove that they do enjoy the process itself. Therefore, designing an extensive reading program based on graded readers will positively affect the learners' language skills development, and in the long run, will potentially improve their language proficiency levels. As for the teacher questionnaires, the findings showed that most English teachers in our region are familiar with the term 'graded reader'. Moreover, more than half of them use them in their EFL classrooms. It can be stated, although the teachers are aware of the positive effects of including graded readers in the language teaching process, certain factors, such as lack of time and learners' interest, often discourage them from doing so.

All in all, we can say that this study and its findings contribute to the pedagogical field of foreign language teaching, as the theoretical parts provide a detailed overview of the main aspects of exploiting literature in EFL settings.

Moreover, the practical part of this study addresses a number of important questions and provides an example of how literature and a graded reader can be used in an actual EFL classroom in our region, as previous studies dealing with this topic/question mainly were conducted abroad.

Although this study managed to provide an insight into this approach, a more detailed and longer study would provide more precise results that would be extremely valuable for foreign language teaching.

\section{References:}

1. Іщук А. А. (2018). Використання сучасної американської літератури як засобу вивчення англійської мови. Наукові записки Національного університету «Острозька академія»: серія «Філологія». Острог : Вид-во НаУОА, 2018. Вип. 1(69), ч. 1, березень. (с. 165-168).

2. Кузнєцова Л.А., \& Лотоцька К.Я. (2000). Неадаптований текст у мовному класі. ЛНУ ім. І. Франка. C. $43-49$.

3. Akbari, O., \& Razavi, A. (2015). Using authentic materials in the foreign language classrooms: Teachers' perspectives in EFL classes. International Journal of Research Studies in Education, 4(5). DOI: https://doi.org/10.5861/ijrse.2015.1189

4. Albay, M. (2017). The Benefits of Graded Readers. International Journal of Social Sciences \& Educational Studies, June 2017, Vol. 3, No. 4, 177-180.

5. Armstrong, M. (2015). Using literature in an EFL context to teach language and culture. The Journal of Literature in Language Teaching, 4(2). URL: http://liltsig.org/wp-content/uploads/2014/12/LiLT-4 2-Armstrong.pdf

6. Bloemert, J., Paran, A., Jansen, E., \& van de Grift, W. (2019). Students' perspective on the benefits of EFL literature education. The Language Learning Journal, 47(3), 371-384.

7. Bobkina, J., \& Dominguez, E. (2014). The Use of Literature and Literary Texts in the EFL Classroom; Between Consensus and Controversy. International Journal of Applied Linguistics \& English Literature, 3(2), 249-260. URL: https://doi.org/10.7575/aiac.ijalel.v.3n.2p.248

8. Cheetham, C., Harper, A., Elliott, M., \& Ito, M. (2016). Assessing Student Attitudes Toward Graded Readers, MReader and the MReader Challenge. The Reading Matrix: An International Online Journal, 16(2). URL: http://www.readingmatrix.com/files/15-in55a2nj.pdf

9. Collie, J., \& Slater, S. (1987). Literature in the language classroom: a resource book of ideas and activities. Cambridge : Cambridge University Press.

10. Daskalovska, N., \& Dimova, V. (2012). Why should Literature be Used in the Language Classroom? Procedia - Social and Behavioral Sciences, 46(46), 1182-1186. Available: https://doi.org/10.1016/j. sbspro.2012.05.271

11. Day, R. \& Bamford, J. (2002). Top ten principles for teaching extensive reading. Reading in a Foreign Language, 14(2). URL: http://www.nflrc.hawaii.edu/rfl/October2002/day/day.html

12. Erkaya, O.R. (2005). Benefits of Using Short Stories in the EFL Context. Asian EFL Journal, November 2005. URL: http://www.asian-efljournal. com/pta_nov_ore.pdf 
13. Ferradas, C. (2009). Enjoying Literature with Teens and Young Adults in the English Language Class. In: BritLit: Using Literature in EFL Classrooms. URL: https://www.teachingenglish.org.uk/article/britlit-usingliteratureefl-classrooms

14. Floris, F. D. (2004) The Power of Literature in EFL Classrooms. English Department, Faculty of Letters, Petra Christian University. URL: http://puslit.petra.ac.id/journals/letters/

15. Hall, G. (2005). Literature in language education. Palgrave MacMillan: New York.

16. Haroon, A., Mohammed, A., \& Khanday, A. (2019). Teachers' Perception of Graded Readers in Motivation EFL Students on Extensive Reading. British Journal of English Linguistics, 7(5), 62-76. URL: https://www.eajournals.org/wp-content/uploads/Teachers-Perception-of-Graded-Readers-in-Motivating-EFLStudents-on-Extensive-Reading.pdf

17. Healy, S. (2010). Literature in the EFL Classroom. From Theory to Practice. URL: https://ksu.repo.nii. ac.jp/?action=repository_action_common_download\&item id=1330\&item no $=1 \&$ attribute id $=22 \&$ file $n o=1$

18. Kaya, S. Ü. (2014). Using Short Stories in ELT/EFL Classes. Başkent University Journal of Education, 1(1), 41-47. URL: http://buje.baskent.edu.tr/index.php/buje/article/view/8

19. Koutsompou, V.-I. (2015). The Use of Literature in the Language Classroom: Methods and Aims. International Journal of Information and Education Technology, 5(1), 74-79. DOI: https://doi.org/10.7763/ ijiet.2015.v5.479

20. Lazar, G. (1993). Literature and language teaching: a guide for teachers and trainers. Cambridge: Cambridge University Press.

21. Lima, C. (2005). Is the rest silence ... ? URL: https://associates.iatefl.org/pages/materials/voicespdf/ ltskills11.pdf

22. Nazara, P. (2019). Learning Vocabularies Using Short Stories at Primary School: Students' Perception. JET (Journal of English Teaching), 5(3), 157. https://doi.org/10.33541/jet.v5i3.1308

23. Pardede, P. (2011). Using Short Stories to Teach Language Skills. JET (Journal of English Teaching), 1(1), 14. URL: https://doi.org/10.33541/jet.v1i1.49

24. Pathan, M. (2012). Advantages of Using Short-stories in ELT Classroom and the Libyan EFL Learners' Perceptions towards them for Developing Reading Comprehension Skill. AWEJ, 1(1), 28-41. URL: https:// awej.org/images/AllIssues/Volume4/Volume4Number1March2013/3.pdf

25. Rai, A. (2012). Use of Literature in Teaching English. International Journal of Educational Research and Technology. Volume 3, September 2012, 71-80.

26. Raveanová, L. (2012). Using Graded Readers in Teaching Adults (Diploma thesis, Masaryk University, Brno, Czech Republic). URL: https://is.muni.cz/th/q65kk/Diploma.Thesis.Raveanova.pdf

27. Scrivener, J. (2005). Learning Teaching. A Guidebook for English Language Teachers. 2nd edition. Macmillan books for teachers.

28. Shella, M. (2016). The Role of Graded Reading Materials in Teaching Reading of EFL Learners. Sriwijaya University Learning and Education International Conference, 2(1), 1075-1086. URL: http:// conference.unsri.ac.id/index.php/sule/article/view/84

29. Skog, E. (2019). Literature in the EFL Classroom: How EFL Teachers in a Few Swedish Secondary Schools Use Novels in Their Classrooms (Thesis, Karlstad University, Karlstad, Sweden). URL: http:// www.divaportal.org/smash/get/diva2:1315807/FULLTEXT01.pdf

30. Tevdovska, E. S. (2016). Literature in ELT Setting: Students' Attitudes and Preferences Towards Literary Texts. Procedia - Social and Behavioral Sciences, 232(232), 161-169. URL: https://doi.org/10.1016/j. sbspro.2016.10.041

31. Waring, R. \& Takahashi, S. (2000). The Oxford University Press Guide to the 'Why and 'How' of Using Graded Readers. Tokyo: Oxford University Press. URL: http://www.robwaring.org/er/articles/Guide_to_Graded Readers e.pdf

32. Yang, C. C. R. (2009). A Case Study of the Use of Short Stories in a Junior Secondary ESL Classroom in Hong Kong. In ERIC (Vol. 16). URL: https://eric.ed.gov/?id=ED545620

\section{Мотринець Е. О., Надь-КоЛожварі Е. А. ВИКОРИСТАННЯ ЛІТЕРАТУРИ НА УРОКАХ АНГЛІЙСЬКОЇ МОВИ: РОЛЬ АДАПТОВАНИХ ТЕКСТІВ ДЛЯ ЧИТАННЯ В ЗАСВОЄННІ АНГЛІЙСЬКОЇ МОВИ ЯК ІНОЗЕМНОЇ}

Загальновідомо, що викладання іноземної мови не є простим завданням. Протягом багатьох років було розроблено незліченну кількість методів вивчення іноземних мов, проте жоден з них не можна вважати досконалим, оскільки їх ефективність залежить від ряду (внутрішніх та зовнішніх) факторів.

Коли йдеться про викладання іноземної мови, зокрема англійської, багато дослідників підкреслюють актуальність використання літератури на уроках іноземної мови. Як зазначає Кауа (2014, с. 41), 
література здатна допомогти учням збагатити свої мовні знання та вдосконалити свої мовні навички. Також часто згадуваним терміном є поняття градуйованих читачів. Згідно з Shella (2016) ефективність градуйованих читачів можна пояснити тим, що вони мають обмежений словниковий запас, а також граматику, шо значно полегшує учням практикування своєї иільової мови та вдосконалення своїх навичок читання.

Таким чином, мета роботи - дослідити ефективність використання художньої літератури у викладанні іноземної мови та провести дослідження, щоб перевірити, чи є практика використання художньої літератури на уроках іноземних мов знайомою вчителям англійської мови на Закарпатті та чи може вона ефективно застосовуватися на уроках.

Таким чином, об'єктом иього дослідження було використання художньої літератури в навчанні іноземних мов, тоді як предметом дослідження було використання градуйованих читачів на уроках іноземної мови.

Намою метою було дослідити використання градуйованих читачів у викладанні іноземної мови з двох точок зору. 3 одного боку - оцінити ставлення викладачів англійської мови на Закарпатті до використання художньої літератури на уроках англійської мови та їхні думки щодо використання градуйованих читачів. 3 іншого боку - перевірити, чи використання градуйованих читачів під час викладання іноземної мови насправді допомагає учням вдосконалити свої мовні навички, а також оцінити ставлення учнів до изього питання.

Ключові слова: викладання іноземної мови, художня література, читання на іноземній мові, градуйовані читачі, Закарпаття. 